\title{
Taking Small Steps Into Elementary School Reading
}

\section{Christopher Robert Cooper \\ Himeji Dokkyo University}

\section{Reference Data:}

Cooper C. R. (2019). Taking small steps into elementary school reading. In P. Clements, A. Krause, \& P. Bennett (Eds.), Diversity and inclusion. Tokyo: JALT.

In this paper I discuss the introduction of reading in public elementary school fifth- and sixth-grade English language classes. The discussion is centred around an extensive reading (ER) project in which 13 learners read graded readers for a 14-month period in the fifth and sixth grades. Each student read an average of 10 books in 2 months and 17 books over the following year. A reading log was completed by the participants, recording comprehension and interest, with the results showing high understanding and interest in graded readers. A self-evaluation survey was conducted. This indicated that ER was enjoyable and useful: High levels of motivation to continue ER were reported. Two learner profiles are discussed in detail focusing on reading pain (The Extensive Reading Foundation, 2011) and changes from negative to positive impressions of reading. Finally, some activities are presented that were used to help bridge the gap towards individual reading.

近い将来、日本では小学校高学年より英語科の授業が始まる。そして授業内容に初めてリーデイングが入る。この論文は、2

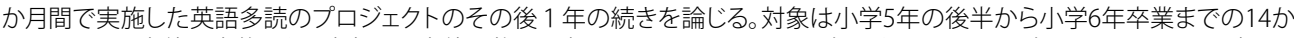
月間、13人の生徒で実施した。読書量は生徒平均で最初の 2 月月間では 10 冊、6年になってからの 1 年間では 17 冊を読んで いた。読書後の生徒達の自己評価では「本の内容が大体分かった」や「本の内容がけっこう面白かった」などの評価が多数だ つた。Reading pain (読書の苦痛; The Extensive Foundation, 2011) と否定的から肯定的な読書への感想の变化に注目しな がっ、そのうち特に大きく動向のあった2人の生徒については、詳しく記述している。最後にリーデイングをサポートするための 他の活動をいくつか記す。

lementary school English is changing. By 2020, all schools in Japan will have English 1 language activities classes once or twice a week in the third and fourth grades and English language classes up to three times a week in the fifth and sixth grades (MEXT,
2014). Fifth and sixth grade classes will include reading and writing, which has not been the case since Foreign Language Activities classes were officially introduced in the fifth and sixth grades in 2011 (MEXT, 2011).

The school involved in this project was a Special English Zone school in the town of Soja, Okayama Prefecture. This meant extra English lessons plus some art, PE, and general studies lessons with an assistant language teacher. It was described by the program as Immersion English. From January 2017 to March 2018, the time of the current study, the school had already met the proposed 2020 guidelines in terms of class time-two 45-minute classes per week in the fifth and sixth grades-plus having extra English time in 15- or 25-minute module classes. With regards to reading instruction, the prestudy curriculum included limited phonics instruction in the form of DVD watching, chants, and worksheets.

\section{Extensive Reading}

\section{Why Extensive Reading?}

According to the input hypothesis (Krashen, 1982), L2 learners will naturally acquire language if they understand what they listen to or read. Ideally, input should be slightly above the learner's current comprehension level. Extensive reading is a natural progression of this theory, in that it involves reading a large amount of easily understandable material (The Extensive Reading Foundation, 2011).

The amount of known vocabulary for learners to comprehend a text comfortably is thought to be $98 \%$ (Schmitt, liang, \& Grabe, 2011). The challenge with reading at the public elementary school level in Japan is getting learners started, as this figure is probably unattainable even with the lowest level books, due to the learners' lack of time spent learning English. 


\section{Extensive Reading With Young Learners}

Some of the earliest extensive reading research was done with young learners. Elley and Mangubhai (1983) implemented the Fiji Book Flood, giving each class in a school a box of around 50 books with which to do self-selected reading. They did the project in rural schools in Fiji to ensure the students' English input was classroom based and found that listening and reading comprehension increased. A similar project was implemented in Singapore initially on a small scale and was eventually adopted by the whole country $(\mathrm{Ng}$ \& Sullivan, 2001).

Despite this, there are not many studies in the field of extensive reading concerning elementary-school-age children. Only six out of 71 studies in Jeon and Day's (2016) meta-analysis focussed on children of this age. These six studies looked at reading comprehension and vocabulary acquisition and showed a mean effect size of $d=0.52$, regarded as a small effect using Plonsky and Oswald's (2014) L2 research-specific guidelines for interpreting effect sizes. However, little to no research had been published on extensive reading in public elementary schools in Japan before the initial stage of the present study (Cooper, 2018). In research into extensive reading at public elementary schools in South Korea (Cho \& Choi, 2008; Cho \& Kim, 2014), researchers found a positive correlation between self-selected reading, student confidence, and interest in learning English.

\section{The Extensive Reading Project}

“. . . and don't worry about the bits you don't understand. Sit back and allow the words to wash around you around you like music" (Dahl \& Blake, 1988, p. 15).

Following an initial 2-month project with learners $(N=38)$ in the fifth and sixth grades (Cooper, 2018), the sixth-grade participants graduated, leaving 17 fifth-grade learners. They continued reading books for a further year, until graduation at the end of the sixth grade. This paper exclusively focusses on 13 of these fifth-grade learners, for whom there is a full data set. Three learners missed at least one self-evaluation and another student transferred to the school in the sixth grade and was not present during the initial 2-month period.

During the project, the learners were given access to reading materials and simply asked to read. They were advised not to worry if they could not read all the words, with the main aim being to understand the story. This practice promotes reading fluency (Day \& Bamford, 2002); guessing the meaning of words in context can lead to vocabulary gains and knowledge of partially known words can be enriched and strengthened
(Webb \& Nation, 2017). With these benefits in mind, as well as the fact that books at this level usually have a picture for every sentence to support reader comprehension, it was hypothesized that the learners' vocabulary deficits would not cause comprehension problems.

\section{Materials}

Each class had a box of books in the classroom, which students could read at any time, and they also read books occasionally during English lessons. To begin with, there were around 50 books in each class, which was increased to around 70 . The books mainly came from three series: Oxford Reading Tree (Levels 1+ to 3), MPI Building Blocks Library (Levels 0 to 3), and Scholastic Guided Science Readers (Levels A and B). These books were chosen because they were the lowest level available from the suppliers used by the school. The levels suited the learners, as they had no prior experience reading English books autonomously. This assumption was supported by the actual selection of books during the study: Not many students read books at Levels 2 and 3 and most read the lowest level books.

\section{Reading Log}

A reading log was completed in which each student recorded the book title, level, a short comment about the book (which could be written in Japanese), and an answer to two Likert-scale questions in Japanese (see Figure 1).

1. How much of the story did you understand?

(1. None 2. A little 3. Most of it 4. All of it)

2 . Was the story interesting?

(1. Wasn't interesting 2. A little interesting 3. Fairly interesting 4. Very interesting)

Figure 1. English translations of reading log Likert-scale questions answered by students.

After 2 months in fifth grade, learners had read 10 books each on average and their average self-reported ratings were 2.91 out of 4 for comprehension and 3.03 out of 4 for interest. In the following year, the average number of books read was 17 , and the selfreported ratings were 2.95 out of 4 for comprehension and 2.92 out of 4 for interest. 
Although the comprehension ratings increased slightly and interest ratings slightly dropped, there was little change between the two periods. Students generally understood most of the books and found them quite interesting. Proportionally, more books were read in a shorter time frame in the first 2 months than the following 1-year period. This may have been influenced by the following factors:

The changing of homeroom teachers: The project may have been insufficiently explained to the new teacher by the researcher, leading to fewer reading sessions in English class.

School events: The initial 2-month period was from January to March, when school events such as Sports Day, swimming practice, and the school play are minimal.

More chances to read in the initial 2-month period: Particularly, several extra reading sessions were held when the researcher was on paternity leave.

\section{Self-Evaluation}

Two self-evaluations were completed, one after 2 months and one a year later. As part of the evaluation, the students answered three Likert-scale questions (based on Cho \& Choi, 2008) in Japanese (see Figure 2).

\section{Did you enjoy reading graded readers?}

(1. No 2. A little 3. Quite enjoyed it 4. Enjoyed it)

2. Do you think reading graded readers is useful for your English education?

(1. No 2. A little 3. Quite useful 4. Useful)

3 . Would you like to continue reading graded readers next year?

$$
\text { (1. No 2. A little 3. I would quite like to 4. Yes) }
$$

Figure 2. English translations of self-evaluation Likert-scale questions answered by students.
Table 1. Self-Evaluation Results After 2 Months $(n=13)$

\begin{tabular}{lllll}
\hline Question & 1 & 2 & 3 & 4 \\
\hline 1. Enjoy & 0 & 5 & 3 & 5 \\
2. Useful & 0 & 5 & 1 & 7 \\
3. Continue & 1 & 3 & 2 & 7 \\
\hline
\end{tabular}

Note. See Figure 2 for actual questions and responses.

The results of the evaluation are shown in Table 1 . After 2 months, the majority of learners were at the highest level of the scale, with a large number indicating they thought reading graded readers was useful and wanted to continue reading them. Only one student stated they did not want to read graded readers in the following year, not even "a little."

Table 2. Self-Evaluation Results After 1 Year and 2 Months $(n=13)$

\begin{tabular}{lllll}
\hline Question & 1 & 2 & 3 & 4 \\
\hline Enjoy & 0 & 4 & 6 & 3 \\
Useful & 0 & 4 & 1 & 8 \\
\hline Continue & 0 & 5 & 6 & 2 \\
\hline
\end{tabular}

Note. See Figure 2 for actual questions and responses.

After the following year, the number of students who stated they enjoyed and wanted to continue reading graded readers was lower (see Table 2), but all 13 students answered at least "a little" to all three questions. The main improvements were that 8 out of 13 students reported reading graded readers was useful and that the one student who had not wanted to continue reading graded readers had now changed her mind.

There was also a space for free comments on the self-evaluation form. No guidance was given to what learners should write, but the comments were coded to look for any patterns in the data. With this group of learners, after 2 months, no significant common themes emerged. However, a year later, five out of 13 students stated that they knew more vocabulary because they had read graded readers. It was never suggested to them that this would be a benefit of taking part in the project, but several of them naturally felt their vocabulary knowledge had increased. This was an interesting and unexpected finding. 


\section{Learner Profiles}

In order to include an accurate, balanced view of all types of learners, particularly ones who did not necessarily fully engage with extensive reading throughout, two learner profiles are presented in detail here.

Learner 1 Profile-Reading Pain

If books are too difficult to comprehend and require a great deal of effort, this can be demotivating for the learner, causing reading pain (The Extensive Reading Foundation, 2011). After around one month of reading graded readers, Learner 1 quite evidently experienced reading pain. He broke down crying whilst reading a book, specifically saying he did not understand why he could not look in a dictionary to understand every word. It was explained to him that he did not need to worry about reading every word, as long as he could understand the gist of the story and read some words.

In his self-evaluation after 2 months, Learner 1 wrote that he could not read the books at all at first, but after 2 months he could read a little and he wanted to read graded readers in the following school year. After 1 year, he wrote that he did not really like reading graded readers but he could enjoy them a bit, as he was able to read more, and that he wanted to try harder to learn English in junior high school.

These comments are an honest reflection from a student who clearly did not really enjoy the experience of extensive reading. However, it may have inspired a determination in him to learn English in junior high school, where reading constitutes a significant part of the curriculum.

\section{Learner 2 Profile-Transformation}

Although Learner 1's position on extensive reading was largely unchanged from the 2-month to 1-year period, Learner 2 showed a transformation in her attitude. After 2 months, she was the one student in this 13 -student sample who stated in her selfevaluation that she did not want to continue reading graded readers in the sixth grade. She also wrote that reading graded readers was difficult, but that she had tried her best.

After a year, her Likert-scale answers in the self-evaluation all increased, particularly her continue rating increased from 1 to 4 and her useful rating increased from 2 to 4 . She also wrote that all of the books she read were easy and that she wanted to try to read more difficult books in junior high school.
During the initial 2-month period, Learner 2 read one Level 3 book from the Oxford Reading Tree, giving it the lowest possible understanding and interest ratings. The remaining 17 books she read were at level 0 or level 1 in the Oxford Reading Tree and MPI Building Blocks Library or level A or B of the Scholastic Guided Science Readers series, the lowest level books available.

Learner 2's experience of reading a higher level book in the initial period followed by lower level books may explain her transformation. It may also suggest a strategy that could be useful for learners at this level: Read lots of books at a lower level to gain confidence to inspire you to move on when you are ready. This strategy fits with extensive reading ideals.

\section{Bridging the Gap}

The approach to reading described in this paper mainly involved reading books with minimal teacher intervention. To scaffold the reading process, the following reading activities were also included in the curriculum to provide bottom-up support by creating interest in stories, introducing letter-sound relationships, and drawing attention to the written form of familiar oral texts.

\section{Whole-Class Picture Book Reading}

To foster children's interest in reading English books on their own, they should at first be interested in English books. Reading books to young children is a well-established activity during L1 learning and can be included in L2 English education as early as kindergarten in public school contexts where English learning begins earlier than the MEXT guidelines. This activity can create interest in L2 literacy, provide visually rich comprehensible input, and be used to introduce a topic or target language in context, among other benefits (Ellis \& Brewster, 2014). Attention should be paid to learner comments in the L1 and L2, as they generally talk about the book or the pictures during storytelling (Cooper, 2016).

\section{Phonics}

Whether synthetic, analytic, or a more basic phonics approach is appropriate in elementary schools in Japan is an area under debate (Kyrala, 2009) and one that requires more research. This topic is too broad to explore in detail here, but most teachers would agree that some form of phonics instruction is necessary when teaching reading. 
At the school discussed in this paper, starting in first grade, pupils watched DVDs including phonics chants and videos introducing single letter sounds, and they played games using alphabet letters. Starting in the fourth grade, they worked through phonics worksheets covering the sounds of consonants, single letter vowels, double letter vowels, and some double letter consonants.

\section{Song Lyrics}

Almost all elementary schools in Japan have students sing a monthly song in Japanese. At the school described in this paper, the monthly song was sung in English. Most mornings, the students would sing the song in their classroom and in English lessons too. There would always be an illustrated lyric sheet on the board to help students sing along, either by looking at the pictures (younger children) or the words (older students).

The children were not told to read the words while singing, but naturally some would. At the end of the month, the fifth- and sixth-grade classes did one literacy activity with the song lyrics. For example, they put cut-out song lyric lines in order, like a puzzle, or they filled in the blanks of missing words on an A4 lyric sheet. The songs included children's classics like "Old MacDonald Had a Farm" and "The Wheels on the Bus" and old pop songs like the Beatles' "Hello Goodbye" or the Carpenters' "Sing," chosen because the lyrics are simple. These activities could also be done with songs that are only sung in English lessons.

\section{Joint Storytelling}

A significant part of the curriculum at this school was dedicated to joint storytelling (Allen-Tamai, 2013), in which students learn simplified, dialogue-based versions of wellknown stories, such as fairy tales. When the fifth- and sixth-grade classes had learned their stories orally, they were given the script to read. Like the song lyric activity, this allows learners to focus their attention on the written form of the language, as they already know the words and the order in which they appear orally.

This kind of activity can also give the teacher an insight into learners' knowledge of phonics and reading progress. During this activity, one student, when reading a line from "Goldilocks and the Three Bears," changed how knock, knock, knock was pronounced by reading the $/ \mathrm{k} /$ and $/ \mathrm{n} /$ sounds separately, even though he knew the story orally. This showed that he was thinking about the individual letter sounds of $/ \mathrm{k} /$ and $/ \mathrm{n} /$ and was making a very logical and valuable mistake. It also gave an opportunity to share with the class that words that begin with kn, like know, knife, or knee are pronounced without saying the $/ \mathrm{k} /$ sound. This point was addressed when it came up naturally in class, possibly making it more meaningful and memorable for the learners.

\section{Limitations and Future Suggestions}

There are several limitations to the findings of this study. First, as comprehension was self-reported and not objectively tested by teachers or researchers, the results may not be accurate. Testing was avoided in this study to avoid putting any extra pressure on the learners in a context where there was little or no testing of English ability at the time of the study. Self-evaluation was chosen as it matched practices that the participants were familiar with.

As the self-reported results were positive, further research in this area would be valuable. Comprehension could be more objectively measured by asking learners to periodically do comprehension quizzes based on individual books or set class graded readers. If this was deemed to be too intrusive, learners could be asked to retell the story of a book they have read to their instructor, either in English or in their L1.

Another clear limitation is the sample size $(n=13)$; if any conclusions from this study were to inspire similar programs to be introduced on a larger scale, replication studies at a range of schools in different areas are necessary. Also, the nonrandomized nature of the sample means that any quantitative results are not generalizable.

Further issues may arise if teachers with larger class sizes attempt to replicate this study, due to the reduced amount of one-on-one reading support they can give. One solution to this problem would be allowing students to listen and read at the same time. This can take the burden of individual letter-sound processing away from students, allowing them to focus on enjoying a story, even if they cannot decode all the words.

Many graded readers include audio CDs or QR code links to downloadable MP3s. In addition to the series used in this project, comic book readers such as the award-winning Vera the Alien Hunter (www.efuture-elt.com) could be popular with elementary school children in Japan. The books in this series also come with a CD and the audio can be downloaded from a free app, so students could take the books home and read them independently or with a parent. Reading traditional English books with parents following training sessions is a topic explored by Ferguson, Sponseller, and Yamada (2017) and could be further investigated using audio graded readers.

There are several online eBook services available, some of which have integrated audio. There is a service linked to the Oxford Reading Tree called Oxford Owl (www.oxfordowl. co.uk), which offers access to many eBooks for free. This could be used at home or in the 
classroom, in conjunction with reading traditional books; for schools with no budget for buying English books, it could be used to introduce them to graded readers.

\section{Conclusion}

In the coming years, there are likely to be several changes to the way elementary school English is taught in Japan. As suggested by the current textbooks provided by MEXT, Let's Try for 3rd and 4th grades, and We Can for fifth and sixth grades (MEXT, 2018), reading and writing are now included in the curriculum, but only at the word and sentence level. The learners in this study read an average of 27 books each in a period of 1 year and 2 months. They found the process enjoyable and useful to some extent and wanted to continue reading English books. Although the sample size was small and issues arose along the way, what these results show is that Japanese learners of English in public elementary school can interact positively with English texts at the discourse level.

\section{Bio Data}

Chris Cooper currently works as an English instructor at Himeji Dokkyo University. He worked as an ALT, mainly in elementary schools, in Okayama Prefecture from 2010 to 2018 and has an MA in TESOL from Sheffield Hallam University. His research interests include extensive reading, extensive listening, and storytelling. <cooperchris17@gmail.com>

\section{References}

Allen-Tamai, M. (2013). Story trees. Tokyo: ShoPro.

Cho, K. S., \& Choi, D. S. (2008). Are read-alouds and free reading "natural partners"? An experimental study. Knowledge Quest, 36(5), 69-73

Cho, K. S., \& Kim, Y. (2014). Can stories and self-selected reading slow the decline in attitudes toward English? The International Journal of Foreign Language Teaching, 9(1), 7-12.

Cooper, C. R. (2016). Scaffolding during the initial reading of picture books in Japanese elementary school EFL classrooms: A qualitative study investigating how teachers and learners co-construct meaning during whole class picture book reading (Unpublished master's thesis). Sheffield Hallam University, Sheffield, England.

Cooper, C. R. (2018). Rakudoku: Fostering the beginnings of extensive reading (with fifth and sixth graders) in a public elementary school in Japan. Journal of Extensive Reading, 6(2). Retrieved from http://jalt-publications.org/content/index.php/jer/

Dahl, R., \& Blake Q. (1988). Matilda. New York, NY: Viking Kestrel.
Day, R. R., \& Bamford, Y. J. (2002). Top ten principles in teaching extensive reading. Reading in a Foreign Language, 14(2), 136-141.

Elley, W. B., \& Mangubhai, F. (1983). The impact of reading on second language learning. Reading Research Quarterly, 19(1), 53-67. https://doi.org/10.2307/747337

Ellis, G., \& Brewster, J. (2014). Tell it again!: The storytelling handbook for primary English language teachers. London, England: British Council.

Ferguson, P., Sponseller, A., \& Yamada, A. (2017). Introducing the family reading project. In P. Clements, A. Krause, \& H. Brown (Eds.), Transformation in language learning (pp. 129-134). Tokyo: JALT. Retrieved from http://jalt-publications.org/sites/default/files/pdf-article/jalt2016pcp-017.pdf

Jeon, E-Y., \& Day R. R. (2016). The effectiveness of ER on reading proficiency: A meta-analysis. Reading in a Foreign Language, 28(2), 246-65.

Krashen, S. D. (1982). Principles and practice in second language acquisition. Oxford, England: Pergamon.

Kyrala, C. K. (2009). Phonics as gateway: EFL reading in primary school. In A. M. Stoke (Ed.), JALT2008 conference proceedings (pp. 1139-1156). Tokyo: JALT. Retrieved from http://jaltpublications.org/recentpdf/proceedings/2008/E041.pdf

MEXT (2011). Foreign language activities. Retrieved from http://www.mext.go.jp/a_menu/shotou/ new-cs/youryou/eiyaku/gai.pdf

MEXT (2014). English education reform plan corresponding to globalization. Retrieved from http:// www.mext.go.jp/en/news/topics/detail/__icsFiles/afieldfile/2014/01/23/1343591_1.pdf

MEXT (2018). 新学習指導要領に対応した小学校外国語教育新教材について [New teaching materials for foreign language education in elementary schools corresponding to the new course of study]. Retrieved from http://www.mext.go.jp/b_menu/shingi/chousa/shotou/123/houkoku/1382162.htm

Ng, S. M., \& Sullivan, C. (2001). The Singapore reading and English acquisition program. International Journal of Educational Research, 35. 157-167. https://doi.org/10.1016/s08830355(01)00013-1

Plonsky, L., \& Oswald, F. L. (2014). How big is "big"? Interpreting effect sizes in L2 research. Language Learning, 64(4), 878-912. https://doi.org/10.1111/lang.12079

Schmitt, N., Jiang, X., \& Grabe, W. (2011). The percentage of words known in a text and reading comprehension. The Modern Language Journal, 95(1), 26-43. https://doi.org/10.1111/j.15404781.2011.01146.x

The Extensive Reading Foundation. (2011). The extensive reading foundation's guide to extensive reading. Retrieved from http://erfoundation.org/guide/ERF_Guide.pdf

Webb, S., \& Nation, P. (2017). How vocabulary is learned. Oxford, England: Oxford University Press. 